\title{
THE BENEFICIAL OWNER OF DIVIDEND INCOME RECEIVED BY A DISCRETIONARY TRUST
}

\author{
Waldette Engelbrecht* \\ Stellenbosch University \\ wdupreez@sun.ac.za
}

Received: November 2013

Accepted: June 2014

\begin{abstract}
In terms of the new Dividends Tax, which came into effect on 1 April 2012, Dividends Tax may be the liability of the beneficial owner of the dividend. This makes it important to correctly identify the beneficial owner. The term beneficial owner is specifically defined in section 64D of the Income Tax Act No. 58 of 1962 as 'the person entitled to the benefit of the dividend attaching to the share', yet a distinct difference remains between the legal ownership and economic ownership of the share. Within a South African context, determining the beneficial owner within a discretionary trust might be problematic. The trustees are the legal owners of the shares, whilst the beneficiaries might be the economic owners of the shares. Further, consideration has to be given to the timing of the dividend distribution. This article formulates steps to determine which person is entitled to the benefit of the dividend attached to the share.
\end{abstract}

Keywords

Discretionary trust, beneficial owner, dividends tax, ownership attributes

*Ms W Engelbrecht is a lecturer in the School of Accountancy, Stellenbosch University, Stellenbosch, South Africa. 


\section{INTRODUCTION}

Dividends Tax came into effect as from 1 April 2012 (National Treasury, 2012:36) and is regulated by Part VIII of the Income Tax Act No. 58 of 1962 ('Act'). Section 64EA of the Act determines that the Dividends Tax liability may fall on the beneficial owner of a dividend, to the extent that the dividend does not consist of a distribution of an asset in specie.

The Act defines the beneficial owner as the 'person entitled to the benefit of the dividend attaching to the share' (section 64D). Dividends Tax per section 64EA(a) of the Act focuses only on the beneficial owner and not on the registered owner of the share. Furthermore, the 'dividend' definition was also amended in section 1 of the Act to the remove the 'shareholder' definition. The Explanatory Memorandum on the Taxation Laws Amendment Bill (2012:35) explains that the shareholder definition encompasses both the share register and beneficial ownership, which could lead to misunderstandings, 'since the person named in the share register is not necessarily the beneficial owner of the share'.

The concept of beneficial ownership is thus a new concept in South African tax legislation and requires clarification in certain instances.

\section{PROBLEM STATEMENT}

From an international perspective, establishing the beneficial owner of income, usually passive income in the form of dividends, interest and royalties, is crucial. The possibility of relief from withholding tax imposed by a foreign jurisdiction in respect of this passive income depends on whether the beneficial owner of the income is resident in the other contracting state (Kruger, 2012).

In terms of the new domestic legislation, Dividends Tax may be the liability of the beneficial owner of the dividend in certain instances (section 64EA(a)). Thus, it is important to correctly identify the beneficial owner and also who would be liable for paying the Dividends Tax. The problem that arises is the question of how the term beneficial owner is interpreted in South Africa and particularly in the case of dividends received by a discretionary trust. Even though the term beneficial owner is specifically defined in section 64D of the Act as 'the person entitled to the benefit of the dividend attaching to the share', a distinct difference remains between the legal ownership and economic ownership of the share. Applying the definition to discretionary trusts might be problematic, as the trustees are the legal owners of the shares who hold the shares on behalf of and for the benefit of the beneficiaries. The beneficiaries, in turn, are the economic owners of the shares (PWC Synopsis, 2012). Depending on how beneficial owner is interpreted, the person entitled to the benefit of the dividend attached to the share can either be the beneficiary or the trust itself (Louw, 2012).

Furthermore, by virtue of section $64 \mathrm{~K}(\mathrm{l})$ of the Act, careful consideration has to be given to the timing of the distribution of the dividend, since this might significantly affect the determination of the beneficial owner of dividend income in the case of a dividend received by a discretionary trust.

Locally and internationally, the meaning of beneficial owner is still debated. Oliver, Libin, Van Weeghal and Du Toit (2000:310) stated that 'there seem to be a number of possibilities or even just uncertainties as to what meaning, or meanings, it [beneficial owner] might have'. Du Toit 
(2010:500) investigated the development of the term beneficial ownership within the context of international taxation and confirmed that there is still much debate about its exact meaning.

In the Model Tax Convention ('MTC') on Income and on Capital as issued by the Organisation for Economic Co-operation and Development ('OECD'), article 10 refers to the term 'beneficial owner', but no further explanation on the meaning of the term is provided. During April 2011, the $0 \varepsilon C D$ issued a public discussion draft, namely the 'Clarification of the meaning of "beneficial owner" in OECD Model Tax Convention' ('Discussion Draft'). This Discussion Draft (2011:3) stipulated that 'the term beneficial owner is therefore not used in a narrow technical sense (such as the meaning that it has under the trust law of many common law countries), rather, it should be understood in its context'. This emphasises the importance of determining the meaning of South Africa's domestic tax law in respect of beneficial ownership.

Honiball and Olivier (2011:545) argue that it is generally accepted that 'South Africa has intended an internationally-accepted meaning of the concept'. This implies that an international meaning must be sought and will be discussed in this article.

\section{OBJECTIVES AND RESEARCH METHODOLOGY OF THE STUDY}

This paper aims to set parameters for determining who the beneficial owner of dividend income within the context of a discretionary trust is; where the dividend is paid in respect of shares held in a resident company; and to the extent that the dividend does not consist of a distribution of an asset in specie.

The research was conducted through a literature review using recent local and international sources available on the internet and took the form of a non-empirical approach. This entailed an extended literature review of government publications, court cases and published articles.

International articles and publications are invaluable, since comprehensive guidance has yet to be provided in South Africa on this particular problem statement. International court cases relevant to beneficial ownership formed a significant part of the research. The international cases are not binding on the South African courts, but do have persuasive value.

In order to achieve this objective, consideration is given to the following in an attempt to clarify and substantiate the aim of this paper:

To analyse the proposed meaning of beneficial owner according to the literature available.

To analyse the factors (as identified in the literature above) that would be applicable to identify the beneficial owner for dividends tax purposes.

To identify further factor(s), such as the timing of distributing the dividend income to the trust beneficiaries, which might affect who the beneficial owner is.

Based on all the factors identified, to analyse the proposed meaning of the term beneficial owner for Dividends Tax purposes.

\section{ANALYSIS OF THE MEANING OF THE CONCEPT BENEFICIAL OWNERSHIP}

The concept of beneficial ownership is unfamiliar in South African common law and the term beneficial owner has also not been comprehensively defined in the Act (Honiball \& Olivier, 2011). 
Interpretation Note No. 43 (2012), whilst issued as guidance by the South African Revenue Service ('SARS') with reference to amounts received from the disposal of shares, confirms that the Act is 'generally only concerned with beneficial ownership'. Specific mention is made of a trustee vesting a share in a beneficiary whereby the beneficiary becomes the beneficial owner of the share from that date.

Section 5(1) of the Tax Administration Act No. 28 of 2011 gives legal standing to the aforementioned, as it specifies that the Interpretation Note is an official publication providing clarity on the interpretation of the Act. Further, Binding Private Ruling: BPR 125 on the vesting of dividends rights to the beneficiary of a discretionary trust could also allude to SARS's interpretation on the meaning of beneficial owner. However, as no comprehensive guide currently exists in South African income tax legislation, it is necessary to investigate international and legal guidance on the matter.

The term beneficial owner is most commonly found in tax treaties to counter treaty shopping and to place a constraint on the use of this decreased tax rate (Baker, 2007). However, the term beneficial ownership is also not clearly defined in tax treaties, although guidance can be gained from the Commentaries to the tax treaties of the $0 \varepsilon C D$, or the 0ECD MTC.

In this section, the concept of beneficial ownership is analysed. The purpose of the analysis is to identify components of the concept of beneficial ownership. This may assist in determining who is liable for Dividends Tax in terms of section 64EA(a) of the Act.

The $0 \varepsilon C D$ MTC and its Commentaries are investigated and used as guidance in the analysis. Before this, however, the domestic law meanings of beneficial ownership are scrutinised. Finally, a study of relevant case law will add to the analysis.

\subsection{Domestic law meanings of beneficial owner}

The concept of ownership is fundamental in both common law and civil law states. The most important difference between these legal systems is that the common law states allow for a segregation of ownership between legal ownership and beneficial ownership, whereas the civil law states do not. The question of ownership is a legal one and assesses the nature of the rights held by different persons (Du Toit, 2010).

In common law jurisdictions, the concept of beneficial rights originates from trust law, where property interests can be divided into legal and beneficial interests. Equitable (beneficial) rights are assigned to the beneficiary and legal rights to the trustee (Krishna \& Gervais, 2009).

Civil law is distinguishable from common law in that it does not formally recognise segregated ownership. Thus a person holds a legal title, but this is subject to rights and obligations in respect of another person. This other person has an enforceable and personal right against the person holding the legal title. Thus, the same effect is achieved as that in the common law (Olivier et al., 2000).

South Africa is a member of the Commonwealth of Nations, but is not generally regarded as a common law state. This is due to its legal system being based primarily on the Roman-Dutch legal system with aspects of English law influencing trust and company law (Honiball \& Olivier, 2011).

The starting point is thus an investigation into the nature and extent of ownership rights or ownership attributes as held by different parties. A person can be the legal owner of an object, 
yet have no right to deal with the object as his own and not carry any risk related to the object. This person will not be the beneficial owner. Olivier et al. (2000:319) define beneficial owner as: '... the person whose ownership attributes outweighs that of any other person'. The ownership attributes referred to above include the 'right to possess, use or manage the income, the capital (including the power to alienate and the ability to consume, waste or destroy), etc'. The beneficial owner also carries the risk in connection with dividend distribution in the case of shares held (Olivier et al., 2000).

In the absence of a clear definition of the concept of beneficial ownership under domestic law, guidance is often taken from the application of the concept under the OECD MTC and its Commentaries.

\subsection{Beneficial ownership in the latest 0\&CD Documentation}

The possible meaning of beneficial ownership will now be discussed in light of OECD documentation. Due to the differing interpretations by courts and tax administrations in applying the concept of beneficial owner in the Articles of the 0ECD MTCs, the Discussion Draft was aimed at clarifying the interpretation thereof (OECD, 2011). The OECD MTC and its Commentaries do not define beneficial ownership, but merely attempt to describe its character (Krishna \& Gervais, 2009) and expands on the beneficial ownership concept (IBFD, 2011).

\subsubsection{Factors to determine the meaning of the concept beneficial owner}

Based on the explanations provided in the OECD Commentaries, possible factors to assist in identifying the beneficial owner will be analysed in the next section(s). These factors are:

- Intermediate recipients;

- Ownership of the underlying assets;

- Trustees;

- Technical meaning.

\subsubsection{Intermediate recipients}

Paragraph 12.4 of the Discussion Draft stipulates that an agent, nominee, conduit company acting as a fiduciary or administrator as the recipient of the dividend is not the beneficial owner (0દCD, 2011).

The reasons given for such a recipient not being the beneficial owner are as follows:

(i) That recipient does not have the full right to use and enjoy the dividend that it receives and this dividend is not its own, and

(ii) The powers of that recipient over that dividend are indeed constrained in that the recipient is obliged (because of a contractual, fiduciary or other duty) to pass the payment received to another person (OECD, 2011).

Therefore, the recipient of a dividend is the beneficial owner of that dividend where that party has the 'full right to use and enjoy' the dividend, unrestricted by a contractual or legal obligation to pass the dividend received to another person. The obligation can originate from relevant legal documents. Facts and circumstances may also show the substance of the transaction and indicate clearly that the recipient does not have the 'full right to use and enjoy' that dividend (OECD, 2011:4). 
In the case of a conduit company, a practical test was formulated which looks at the relationship and role of the conduit company. This test examines the governance model and composition of the conduit company's parent board and its actual duties of corporate management. The greater the degree of legal responsibilities of the conduit's boards of management, the greater the likelihood that the conduit is both the legal and beneficial owner of its subsidiary's shares and the associated income (Krishna \& Gervais, 2009).

\subsubsection{Ownership of the underlying assets}

In determining who the beneficial owner is, legal ownership of the shares is not the decisive factor if that party has narrow powers in relation to the income derived from the share (Kemmeren, 2012). The Commentaries state that the beneficial owner has the full right to use and enjoy the dividend income without an obligation to pass the income on to another person. This obligation may arise from legal documents or on account of facts or circumstances indicating that, in substance, the recipient does not have the full right of use. Thus the use and enjoyment of the dividend income is not necessarily related to the legal ownership of the share; neither is it related to the use and enjoyment of the share on which the dividend is paid (OECD, 2011).

\subsubsection{Trustees}

As mentioned earlier, the beneficial owner has the full right to use and enjoy income. A footnote to the Discussion Draft states that trustees of a discretionary trust can be the beneficial owners of undistributed dividend income. However, this approach of the OECD has been questioned, since it is trite law that a trustee cannot have full rights over income (IBFD, 2011).

\subsubsection{Technical meaning}

Domestic law, particularly trust law, does not define the concept of beneficial ownership (IBFD, 2011). The Discussion Draft's proposed clarification indicates that term should be interpreted as a global concept and 'be given an international meaning not derived from the domestic laws of contracting states'. This appears to agree with the decision reached in the U.K. Court of Appeal in the case of Indofood International Finance Ltd v JP Morgan Chase Bank NA (Ernst \& Young, 2011). This case, as well as other relevant cases, will be discussed in the following section.

\subsection{Judicial interpretation of beneficial ownership}

The issue of what is meant by the beneficial owner of a dividend has not come up for decision by a South African court (SAICA, 2009). Five international landmark cases, which represent judgements from countries using both civil and common law systems, have been chosen. Although not all these cases addressed the beneficial ownership of dividend income, important factors that arise from all of them may be useful in the analysis of the concept.

\subsubsection{Beneficial ownership in relation to interest income}

\subsubsection{Indofood International Finance Ltd v JP Morgan Chase Bank}

The meaning of the concept beneficial ownership in relation to interest was the subject of a United Kingdom court judgement in the Indofood International Finance Ltd v JP Morgan Chase Bank ('Indofood') case in 2006. The interpretation of beneficial owner as given by the OECD reports and Commentaries on the OECD MTC was upheld by the decision in this case (Interfis, 2009). 
An Indonesian company needed a loan for business purposes and established a Mauritian company to issue the loan in order to benefit from the Indonesian-Mauritian Tax Treaty. The loan amount and the interest rate were identical to that which the Mauritian company borrowed and subsequently lent to the Indonesian parent. The Mauritian subsidiary was obligated to on-pay all the interest received and could retain none thereof. Subsequently, a Dutch incorporated company was interposed between the Indonesian and Mauritian company (Baker, 2007). Refer to FIGURE 1 for an illustration of the tax planning scheme.

The court decided that the Dutch company could not be the beneficial owner of the interest paid by Indofood (Baker, 2007). The beneficial owner of the interest was the party having the full privilege to benefit from the income and not the formal owner. The Mauritian, and later the Dutch, companies were only administrators of the income and thus were not the beneficial owners of the interest income (Kemmeren, 2012). This is also referred to as the economic substance or practical matter test (Du Toit, 2010).

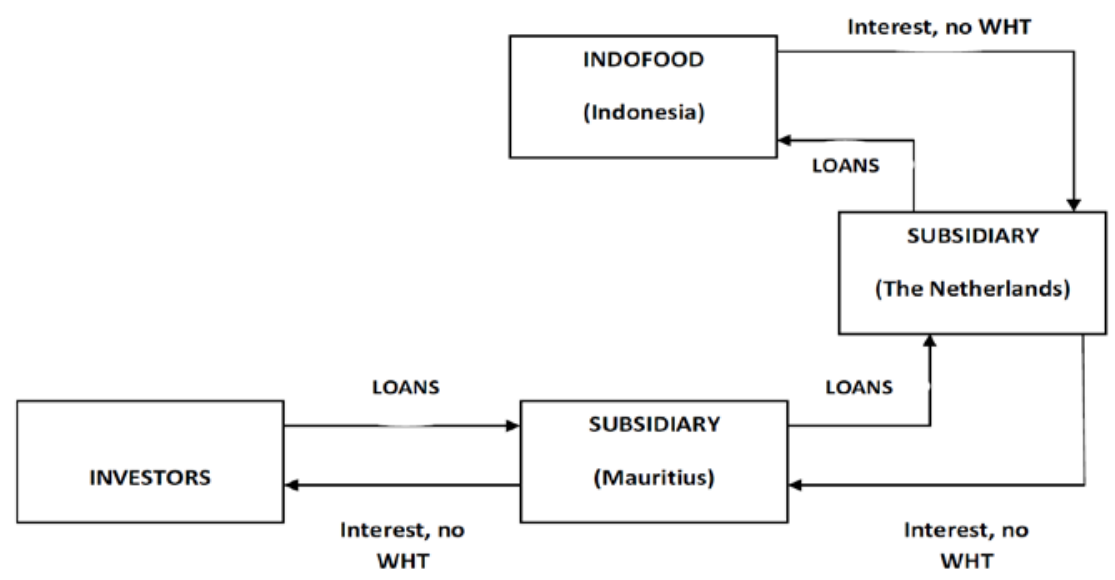

FIGURE 1: The tax planning scheme in the Indofood case

Source: Vitko, 2011

\subsubsection{Beneficial ownership in relation to dividend income}

\subsubsection{Swiss Federal Administrative Tribunal}

The Swiss Federal Administration Tribunal ('Swiss administration court') defined beneficial owner from a tax treaty perspective by using a 'substance over form' or 'economical' perspective (PWC Newsflash, 2012).

Total return swap transactions relating to Swiss equities were entered into between a Danish bank and parties in the European Union and the United States. Once the total return swaps reached maturity, the shares were sold to different parties. Dividends received during the maturity period of the trade were subject to Swiss withholding tax. The Danish bank was found to be beneficial ownership of the dividend (PWC Newsflash, 2012).

In the court's decision, beneficial ownership was analysed using the underlying economic reality, and the following factors were decisive in determining beneficial ownership: 
(a) Firstly, to what extent does the recipient of the dividend income have authority and power to decide on the use of that income? Thus a fiduciary or manager who acts on behalf of the beneficial owner is excluded from beneficial ownership. Being obligated to pass on income to another, shows limited power to decide on the use of the income.

(b) Secondly, who assumes the risks associated with the income? The more risks assumed, the greater the indication of beneficial ownership (Federal Administrative Tribunal Judgement, 2012).

\subsubsection{Netherlands Supreme Court Case no. 28638}

The Netherlands Supreme Court ('HogeRaad') decision also related to treaty interpretation of beneficial ownership. In this case, a stockbroker residing in the United Kingdom purchased dividend coupons of Royal Dutch Shell from a Luxemburg company. The stockbroker did not purchase the underlying shares of Royal Dutch Shell. These coupon rights were purchased after Royal Dutch Shell had declared, but not yet paid, its dividend. The HogeRaad held that the stockbroker was the beneficial owner of the dividend (Krishna \& Gervais, 2009). The principle established in this case confirmed that the beneficial owner does not have to be owner of the shares.

\subsubsection{Prévost Car Inc v Her Majesty the Queen}

In the case of Prévost Car Inc v Her Majesty the Queen 2008 TCC 231 ('Prévost'), the shares of a Canadian company ('Prévost Canada') were jointly held indirectly by Volvo in Sweden and Henlys in the United Kingdom. A Dutch company ('Prévost BV') was incorporated between the two shareholders and Prévost Canada (Du Toit, 2010). Prevost BV was created to benefit from reduced withholding tax on dividends in the Netherlands-Canada Double Tax Treaty. In terms of a shareholders agreement with Volvo and Henlys, $80 \%$ of the earnings of Prévost Canada were to be distributed to the shareholders. Thus dividends were declared to Prévost BV and then distributed by Prévost BV to Volvo and Henlys (Vitko, 2011). The court had to decide whether or not Prévost BV was the beneficial owner of the dividend declared by Prévost Canada. It was decided that Prévost BV and not the United Kingdom or Swedish companies were the beneficial owners of the dividend. A key factor in reaching this decision was to determine how much discretion Prévost BV was entitled to exercise with regard to its income (SAICA, 2009). FIGURE 2 illustrates the corporate structure.

Firstly, in terms of the use of intermediaries in the form of agents, nominees or conduit companies, the Honourable Gerald J. Rip, Associate Chief Justice of the Tax Court of Canada, referred to the $0 E C D$ Commentary and noted that an agent, nominee or conduit company 'never has any attribute of ownership of the dividend' received (Prévost Car Inc and Her Majesty the Queen 2008 TCC 231:17).

Secondly, Rip GJ went on to describe the meaning of beneficial owner in relation to the dividend by stating the following:

In my view the "beneficial owner" of dividends is the person who receives the dividends for his or her own use and enjoyment and assumes the risk and control of the dividend he or she received. The person who is the beneficial owner of the dividend is the person who enjoys and assumes all the attributes of ownership. In short, the dividend is for the owner's own benefit and this person is not accountable to anyone for how he or she deals with the dividend income. (Prévost Car Inc and Her Majesty the Queen 2008 TCC 231) 
The distinct focus of the beneficial ownership test was on the payment of the dividend, and not the share, which illustrated that the beneficial owner of the dividend need not be the owner of the share (SAICA, 2009).

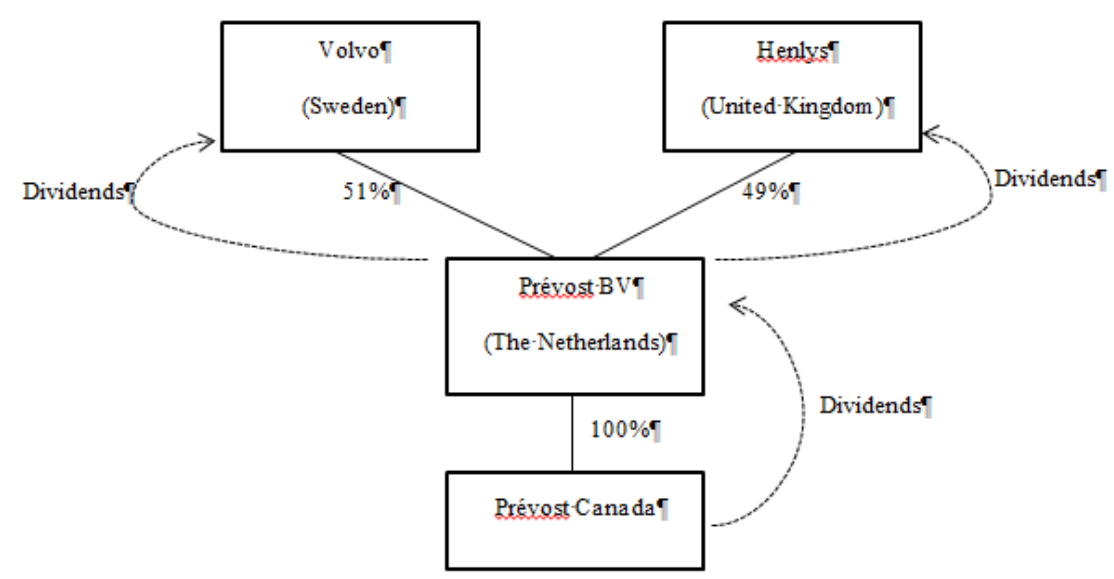

FIGURE 2: The corporate structure in the Prévost case

Source: Vitko, 2011 (Adapted)

\subsubsection{Beneficial ownership in relation to royalty income}

\subsubsection{Velcro Canada Inc $v$ The Queen}

The Tax Court of Canada issued judgement on 24 February 2012 in the case of Velcro Canada Inc $v$ The Queen 2012 TCC 57 ('Velcro') whereby the meaning of the term beneficial ownership was analysed for purposes of a tax treaty relating to royalty income. Velcro Canada Inc. ('Velcro Canada') manufactured and sold fastening products. Velcro Canada had licensed these brands and technologies from a connected Dutch company ('VIBV'). Velcro Canada paid royalties to VIBV and withheld and remitted ten percent of these royalties in accordance with the relevant Treaty provision. VIBV transferred its rights under the license agreement with Velcro Canada, to a wholly-owned Dutch subsidiary ('Dutchco'). Velcro Canada had to pay all royalties to Dutchco, who was then required to pass a certain percentage of these royalties onward to VIBV. The Tax Court held that Dutchco was not the beneficial owner of the royalties and that the beneficial owner was in fact VIBV (Peters, 2012).

The court took the following four elements into consideration when determining beneficial ownership: (a) possession; (b) use; (c) risk; and (d) control of the payment of income (Velcro Canada Inc v The Queen TCC 572012).

\subsection{Summary of factors to determine the beneficial owner}

In FIGURE 3, the factors to determine the beneficial owner as extracted from the analysis of the domestic law meanings, $0 \varepsilon C D$ documentation and judicial interpretations are outlined. Du Toit (2010) confirmed that the meaning of beneficial ownership in essence is that of the common law, and that this was the starting point for the interpretation of the meaning of the concept. Beneficial ownership can be determined by the nature and extent of the rights and obligations of 
the parties, and this is determined by the specific circumstances of each case. Formal legal title cannot constitute beneficial ownership unless the person has a right, at least to a certain degree, to deal with the property as his own. The beneficial owner will be the person whose ownership attributes outweighs that of any other person (Du Toit, 2010).

The five international cases confirm the importance of the ownership attributes as a factor to determine the beneficial owner. In each case, it was evaluated according to who has discretion, authority and power to make decisions regarding the income generated by the underlying asset.

Two parameters can thus be defined to determine whether a person possesses ownership rights or attributes, either of which has to be met:

Parameter one: ownership rights or attributes belong to the person who has the use and enjoyment of the dividend income.

Parameter two: ownership rights or attributes belong to the person with the discretion, authority and power to make decisions regarding the dividend income.

The 0हCD's Discussion Draft further defines this explanation by the explicit exclusion of agents, nominees and conduit entities. A practical test is provided to assist in identifying a conduit entity by investigating the degree of management responsibility. Ownership of underlying assets generating the income is not the deciding factor; instead who has the use and enjoyment of the income from that asset has to be determined.

The factors outlined in FIGURE 3 are combined in FIGURE 4. This forms the basis of determining the beneficial owner of dividend income in a discretionary trust. Before these factors can be applied to determine who is liable for Dividends Tax, it is necessary to have an understanding of the nature of a trust, as well as of the rights and obligations of trustee and trust beneficiary in terms of the trust property.

\section{TRUSTS IN SOUTH AFRICA}

The Trust Property Control Act No. 57 of 1988 ('Trust Property Control Act') was promulgated in South Africa, and section $1(\mathrm{a})$ defines a trust as an arrangement whereby a trust instrument bequeaths ownership in property over to a trustee to be administered for the benefit of persons designated in such trust instrument.

Further, the trust estate is described as a separate entity; it does not have a legal personality. The rights and obligations vest in the trustees and the trust can only act through the trustees, as specified in the trust deed (Cameron JA in Land and Agricultural Bank of SA v Parker and others (2005(2) SA 77 (SCA)). The statement drawn from this case, that a trust is not a legal person, however, is subject to any statutory definition (De Koker \& Williams, 2012). The Act defines a 'person' as including 'any trust' (section 1). This implies that the trust is a separate taxpayer and the trustees are representative taxpayers in respect of the trust (De Koker \& Williams, 2012). The Act defines a trust in section 1 as a 'trust fund consisting of cash or other assets which are administered and controlled by a person acting in a fiduciary capacity'.

It follows, then, that a trust can be subject to tax in its capacity as a person (De Koker \& Williams, 2012). The different parties to a trust are discussed next, followed by a discussion of the ownership of the trust property (capital and/or income). 

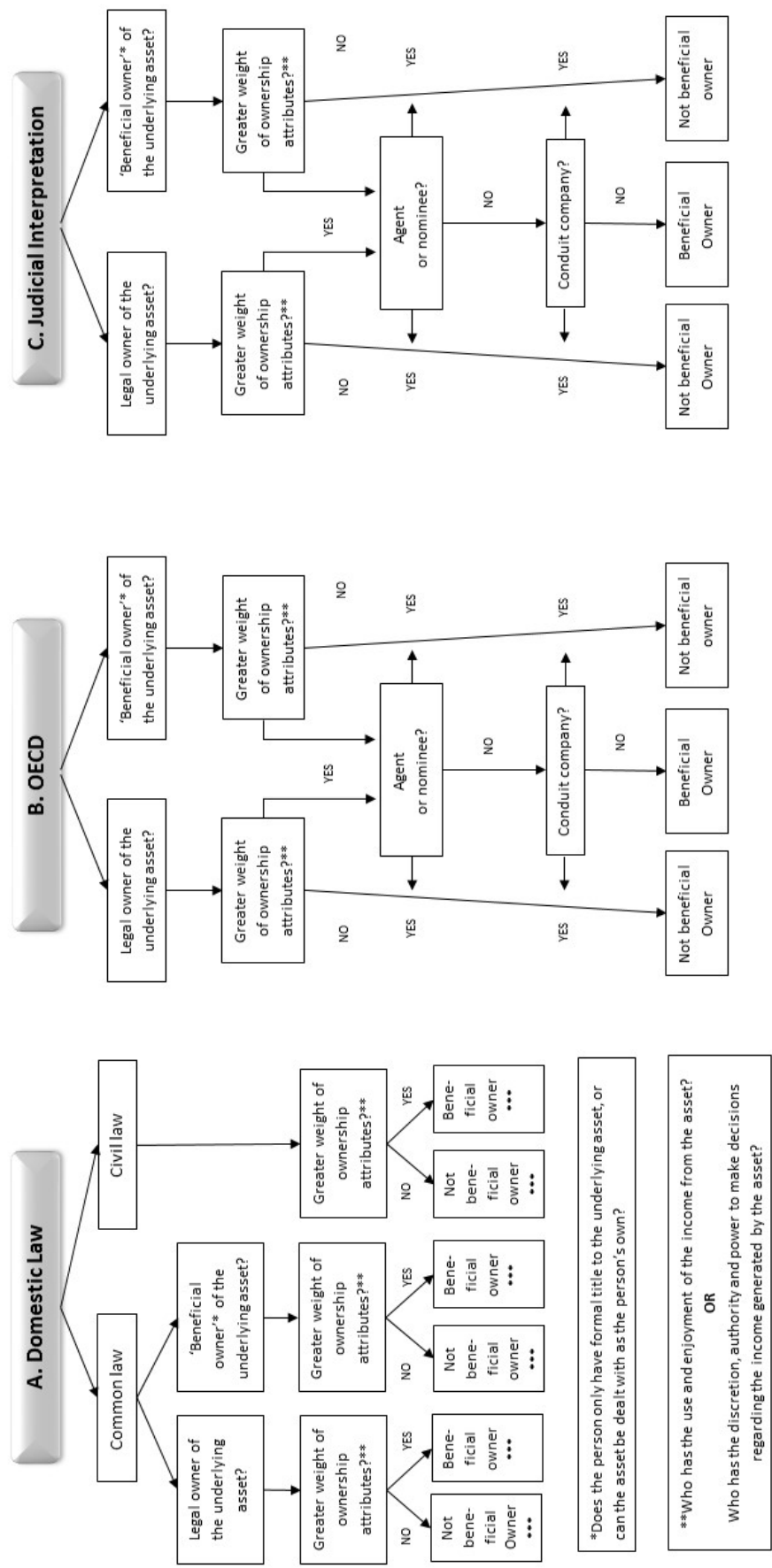

FIGURE 3: The factors in determining the beneficial owner

Source: Compiled by author 


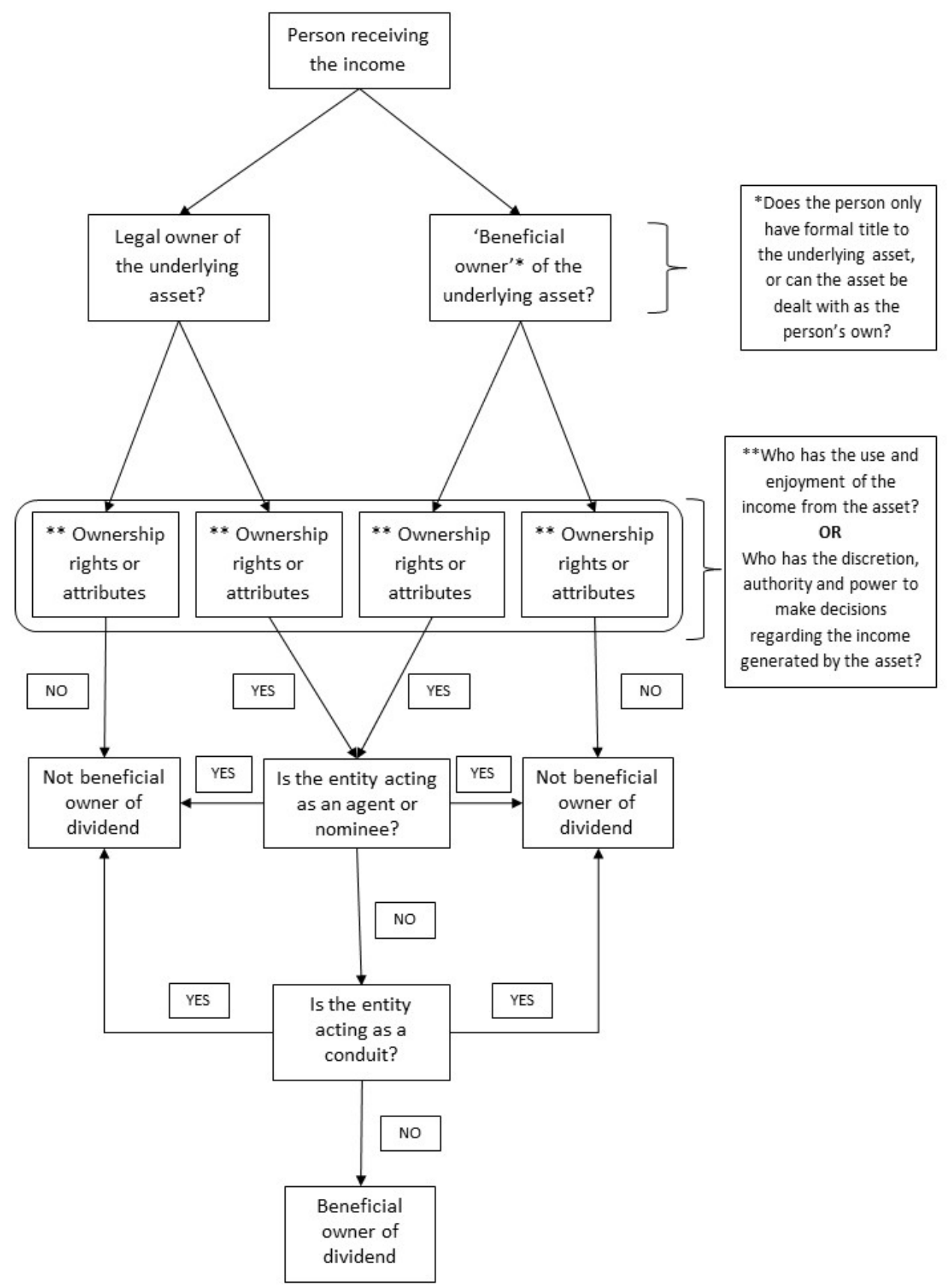

FIGURE 4: The factors in determining the beneficial owner (combined from FIGURE 3)

Source: Compiled by author 


\subsection{The trustees}

Section 1 of the Act defines a trustee as any person who administers or controls property subject to a trust or acts in fiduciary capacity. The fiduciary duty is a responsibility to conduct trust administration prudently and in the utmost good faith (Du Toit, 2002). Section 9(1) of the Trust Property Control Act instructs the trustee to act with the 'necessary care, diligence and skill' when performing his duties and exercising his powers, as is 'reasonably expected of someone who manages the affairs of another'. Given the fact that trustees act in a fiduciary capacity, it is also necessary to consider the powers of the trustees.

The trustee's powers are determined by the trust deed and this stipulates how trust property should be managed. Thus, trustees may not act over and above the powers that are granted to them in the trust deed (Olivier, 1990).

\subsection{The beneficiaries}

Trusts are predominantly set up to benefit trust beneficiaries. The interests or rights of the beneficiary are determined by the terms and conditions of the trust deed, or by the manner in which the trustees have exercised their discretion in favour of the beneficiaries, in accordance with the trust deed. Two types of rights could exist, namely discretionary rights and vested rights (Geach \& Yeats, 2007:20).

A discretionary right means that the beneficiary can only benefit from income and/or capital, in accordance with the trust deed, and to the extent that the trustees have exercised their discretion. At this stage the beneficiaries have a personal right against the trustees to administer the trust in accordance with terms and conditions of the trust deed (Geach \& Yeats, 2007).

A discretionary right becomes a vested right to income and/or capital once the trustee has exercised his/her discretion and made the decision to distribute income and/or capital to the beneficiaries. This vested right can now be regarded as a personal right against the trustees and income and/or capital or the transfer of an asset can be claimed (Geach \& Yeats, 2007).

Despite the discretionary or vested rights that beneficiaries might have to the income and/or capital of the trust, in accordance with the trust deed and the discretion of the trustees, it is important to consider the ownership of trust assets.

\subsection{Ownership of trust property}

The case of Braun v Blann \& Botha (1984(2) SA 850 (A)) emphasised that the trustee was the owner of the trust property, although not for his personal benefit (legal ownership), and that the benefits of the trust property belong to the income and/or capital beneficiaries of the trust (beneficial ownership) (Olivier, 1990). This legal ownership is also referred to as bare or nonbeneficial ownership. This ownership is not beneficial ownership, since trust property is administered in accordance with the trust deed for the benefit of the trust beneficiaries. The property, liabilities, rights and duties of the trust vest in the trustee in his official capacity only (Geach \& Yeats, 2007).

The distinction between legal and beneficial ownership emphasises the fiduciary obligation whereby the trustee acts in an official capacity on behalf of the beneficiaries and not in his private capacity on his own behalf (Honoré \& Cameron, 1992). 
Since legal ownership of the trust assets vests in the trustees, any income derived from such property is received by or accrued to the trustees. The content of the trust deed determines the extent of the beneficiaries' rights and whether they have a claim to the property (income and/or capital) (Olivier, 1990).

In terms of income beneficiaries, the trust deed must be consulted to determine whether the beneficiary's right to the income of the trust is a vested or a contingent right. Once vested, thus stipulated as a vested right by the trust deed or by means of the trustees exercising their discretion to distribute the income, the income will be an asset in the beneficiary's estate (Olivier, 1990).

As the trust deed determines the rights of the beneficiaries to the income of the trust (Olivier, 1990), one has to consider the implications when the trust deed stipulates that the trustees have discretion over the trust income and there is a contingency attached to that discretion. An example is where the trust deed stipulates that trust income can be distributed in accordance with the trustees' discretion at the end of a specified period only if a beneficiary conducts himself/herself in an orderly and acceptable manner for the duration of that period. The trust deed could therefore grant the trust founder, under certain circumstances, the right to recall a beneficiary's right to income from the trust (Stiglingh, Koekemoer, Van Schalkwyk, Wilcocks \& De Swardt, 2013). Another example is where the trust income can only be distributed to a beneficiary according to the trustees' discretion if and once the beneficiary reaches the age of 25 years (for example). In both these instances there is a probability that the income will never be distributed to the beneficiary.

In the case of a discretionary trust where the trustees have discretion to distribute any income, the beneficiary's vested right arises only when the trustee has exercised his discretion. The fact that income is taxed in the hands of the beneficiary in terms of the Act confirms this vested right (Olivier, 1990).

Combining the factors identified in section 4 , with the prior discussion of a discretionary trust, the beneficial owner of dividend income of a discretionary trust is considered next.

\section{DETERMINATION OF THE BENEFICIAL OWNER OF DIVIDEND INCOME IN A DISCRETIONARY TRUST}

The possible factors to determine the beneficial owner of dividend income were summarised in FIGURE 4. Based on this summary, the following steps have been formulated to reach a conclusion:

- Step 1: Identification of the legal owner of the underlying asset (the share).

- Step 2: Identification of the beneficial owner of the underlying asset.

- Step 3: Determining whether the legal owner and beneficial owner of the share have ownership rights or attributes in terms of the dividend income.

- Step 4: Determining whether the entity possessing ownership rights is acting as an agent or nominee or conduit.

Each of the abovementioned steps is illustrated in FIGURE 5. This is the basis for the discussion in the sections that follow. 


\subsection{Identification of the legal owner of the underlying asset}

In terms of this paper, the underlying asset is the share giving rise to dividend income. It is in the trustees' fiduciary capacity that they are the owners of the shares, which are always administered for the sole and exclusive benefit of the trust beneficiaries (Olivier, 1990), and thus a form of non-beneficial ownership of the underlying asset (Geach \& Yeats, 2007).

\subsection{Identification of the beneficial owner of the underlying asset}

In order to be the beneficial owner of the underlying shares, the person has to be able to deal with the shares as his/her own (Olivier et al., 2009). Even though the beneficiary does not hold the legal title to the shares in accordance with trust law, he/she does have a right to enforce the terms of the trust deed, which may stipulate that he/she acquires final ownership of the shares (Krishna \& Gervais, 2009).

In terms of a discretionary trust, the beneficiary has a vested right only once the trustees have exercised their discretion in respect of the distribution of the shares (Olivier, 1990). This gives the beneficiaries a personal right to claim the shares (Geach \& Yeats, 2007), and the beneficiaries can be considered the beneficial owners of the shares. The findings in Braun $v$ Blann \& Botha (1984(2) SA 850 (A)) support this view of equitable (beneficial) ownership belonging to the trust beneficiaries.

However, according to the OECD's Discussion Draft, ownership of the underlying asset that is generating the income is not the deciding factor; rather the party who has the use and enjoyment of the income from that asset is (OECD, 2011). The next step is to determine whether the trustees (legal owners) or the beneficiaries (beneficial owners) possess ownership rights or attributes in terms of the dividend income.

\subsection{Determining whether the legal owner and beneficial owner of the share have ownership rights or attributes in terms of the dividend income.}

In section 4 of this study it was established that the allocation of ownership rights or attributes is a legal question and that the nature of the rights held by the trustees and beneficiaries has to be considered ( $\mathrm{Du}$ Toit, 2010). Two parameters were set to determine whether a person possesses ownership rights or attributes, either of which has to be met. Given the nature of the rights of the trustees and beneficiaries, as explained in section 5 , a discussion of these two parameters will follow.

As the trust deed determines the right of the beneficiaries to the income of the trust (Olivier, 1990), one has to consider the implications thereof. As discussed in section 5.3, there may be instances where the beneficiaries may never become entitled to the trust income. The following two practical examples have been selected to illustrate different trust deed specifications:

\section{Example 1}

The trust deed specifies that the trustees have discretion over the trust income, the discretion is exercised and income is distributed to the beneficiaries. 


\section{Example 2}

The trust deed specifies that the trustees have discretion over the trust income and there is a contingency attached to that discretion making the trustees' discretion subject to a contingency (or an uncertain future event). This would be the case where the trust deed stipulates that trust income can only be distributed in accordance with the trustees' discretion at the end of a specified period if a beneficiary conducts himself/herself in an orderly and acceptable manner for the duration of that period. A similar case is where the trust income can be distributed to a beneficiary according to the trustees' discretion only if and once the beneficiary reaches the age of 25 years. In both these instances there is a probability that the income will never be distributed to the beneficiary.

With the above trust deed specifications in mind, one can now consider the ownership rights or attributes parameters using the abovementioned two examples.

\subsubsection{Parameter one: Use and enjoyment of the dividend income}

\subsubsection{Example 1 (Refer FIGURE 5)}

In Example 1 it is assumed that trustees have exercised their discretion and distributed dividend income to the beneficiaries of the trust. Even though dividend income derived from the shares is received by or accrued to the trustees (Olivier, 1990), it is a characteristic of a South African trust that the trustees only act in a fiduciary capacity and administer the dividend income on behalf of the beneficiaries (Honoré \& Cameron, 1992).

Furthermore, $0 \& C D$ commentary stipulates that, where a 'formal owner' of an asset has very narrow powers, such as the trustee, such person would not be the beneficial owner of the income concerned, as its role is a 'mere fiduciary or administrator' acting on account of the true beneficial owners (OECD, 2011:3). Once the trustees have exercised their discretion, the beneficiaries of the discretionary trust may demand the delivery of the dividend income, since their right to the dividend income is vested (Geach \& Yeats, 2007). It can therefore be concluded that the beneficiaries, and not the trustees, have the use and enjoyment of the dividend income and possess ownership rights or attributes in terms of the dividend income.

\subsubsection{Example 2 (Refer FIGURE 5)}

In Example 2 it is assumed that the trustees have not exercised their discretion to distribute dividend income to the beneficiaries and there is a possibility that the income might never be distributed to the beneficiaries (due to a contingency). Until the trustees have exercised their discretion and the fulfilment of the contingency, the beneficiaries only have a right against the trustee for proper administration of the trust. The beneficiaries are not entitled to the trust assets and have only a contingent right, or hope, to them (Louw, 2012). It might be questionable whether the trustees can be the beneficial owners, since they do not have full rights over the income in accordance with trust law (IBFD, 2011).

It has been suggested that the trust, with the trustees, acting in their official capacity on behalf of the trust, could be seen as the beneficial owner of the dividend income (0ECD, 2011). Bearing in mind that ownership attributes have to be weighed up (Olivier et al., 2000), it is plausible for the trust to be the beneficial owner (Louw, 2012). This will be the case in Example 2. Also, in terms of the Act, the trust is recognised as a person for Income Tax purposes (section 1 ) and the trust could be subject to tax in its capacity as a person (De Koker \& Williams, 2012). 


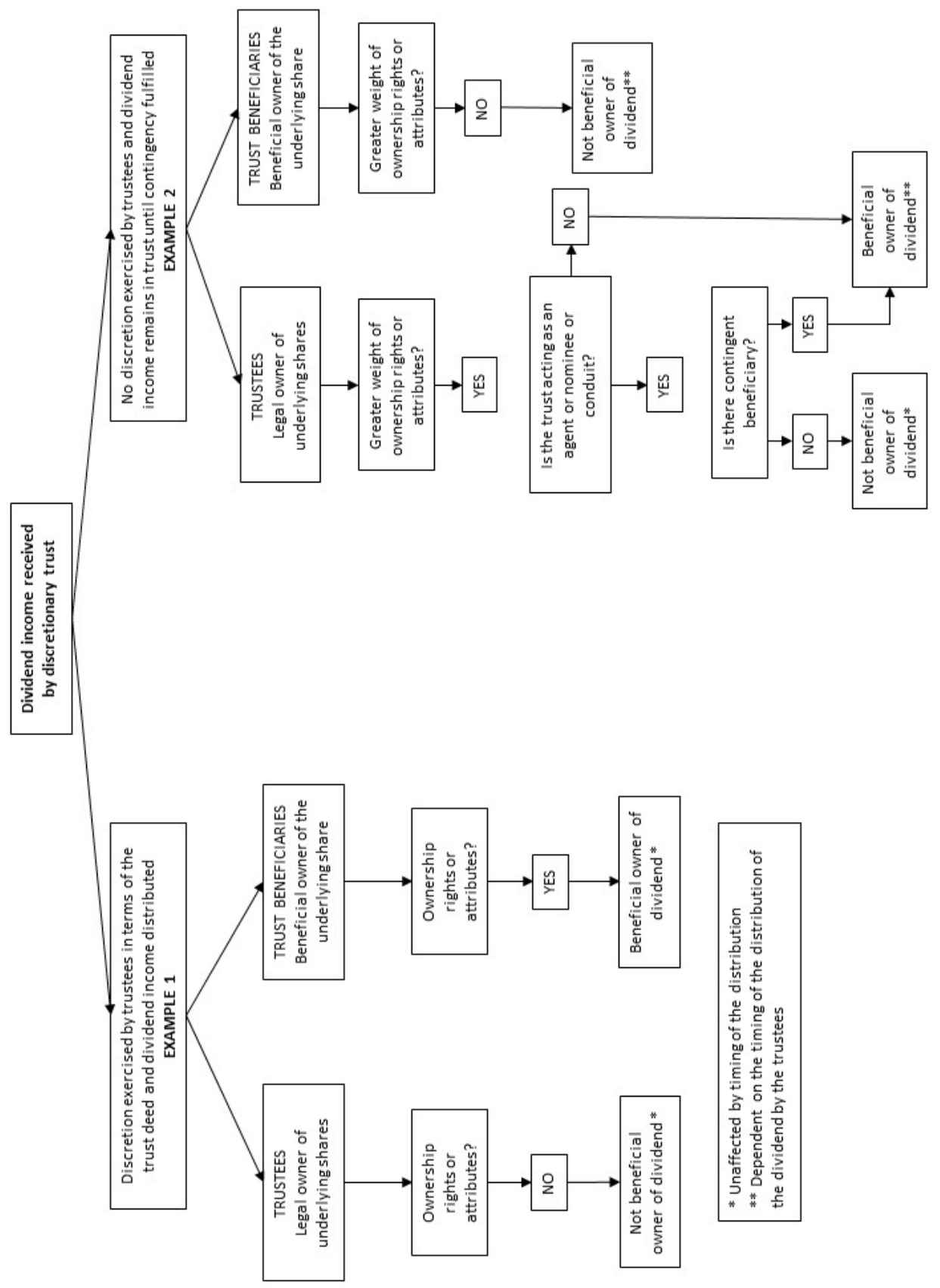

FIGURE 5: The beneficial owner of dividend income received by a discretionary trust

Source: Compiled by author 


\subsubsection{Parameter two: Discretion, authority and power to make decisions regarding the dividend income}

\subsubsection{Example 1 (Refer FIGURE 5)}

In terms of the second parameter, the discussion concerns whether it is the trustees or the beneficiaries who have the discretion, authority and power to make decisions regarding the dividend income. This discussion commences with the assumption that the trustees have exercised their discretion and distributed dividend income to the beneficiaries of the trust.

In the Velcro case, the following elements were taken into consideration when determining beneficial ownership: (a) possession; (b) use; (c) risk; and (d) control of the payment of income (Velcro Canada Inc v The Queen TCC 57, 2012). These traits of beneficial ownership were postulated in the Prévost case (Kruger, 2012). Since it has been put forward that South Africa intends to adopt an internationally accepted meaning for the term, Kruger (2012) concludes that elements of beneficial ownership as proposed by the Canadian courts provide a reasonable basis for possible interpretation of beneficial ownership of dividend income from a South African perspective.

Section 5 of this study established the principle that the trustee is the legal owner of the shares that give rise to the dividend income. However, the Trust Property Control Act stipulated in its definition of a trust that, even though ownership of the trust property was bequeathed to the trustee, it was always for the benefit of the beneficiaries in accordance with the trust deed. Further, the trustees' powers are always limited to those granted in the trust deed (Olivier, 1990:76). Thus possession, use and control of the payment of the dividend income are determined by the conditions of the trust deed. Combining this with the fact that the trustees are acting in an official capacity, and not a personal capacity (Honore \& Cameron, 1992), the elements identified in the Velcro case point to the beneficiaries of the trust as possessing ownership attributes and being the beneficial owners of dividend income.

The above view is substantiated by the Swiss administration court's decision. It was held that a person acting in a fiduciary capacity could not be the beneficial owner, since the obligation to pass on income to another displayed limited authority and power in respect of the income (Federal Administrative Tribunal Judgement, 2012). In terms of this interpretation, the ownership attributes of the beneficiary still outweigh those of the trustees. Thus, similar to the conclusion reached in respect of parameter one, it be concluded that the beneficiaries, and not the trustees, have the use and enjoyment of the dividend income and possess ownership rights or attributes in Example 1.

\subsubsection{Example 2 (Refer FIGURE 5)}

Assuming that the trustees have not exercised their discretion to distribute dividend income to the beneficiaries, the ownership attributes of the trustees and the beneficiaries have to be weighed up. The beneficiaries are still not entitled to the trust assets and only have a contingent right to them (Louw, 2012) until the trustees have exercised their discretion and the contingency has been fulfilled. Although the trustees do not have full rights over the income (IBFD, 2011), the discretion, authority and power to make decisions regarding the dividend income lies with the trustees for the greater part. Thus it can be argued that the trust is still the beneficial owner of dividend income in the case of Example 2, reaching the same conclusion as that in terms of parameter one. 
In the preceding steps, it was identified that the trust, with the trustees acting as representative taxpayers, was the possible beneficial owner of the dividend income in the case where dividend income remained undistributed and the trustees did not exercise their discretion (due to a contingency contained in the trust deed). Lastly it is necessary to consider whether the trust can be seen as an agent, nominee or conduit in respect of the dividend income not distributed by the trustees.

\subsection{Determining whether the beneficial owner is acting as an agent, nominee or conduit}

The discussion in section 5 established that intermediate recipients of the dividend income, namely agents, nominees or conduit companies acting as a fiduciary or administrator, cannot be the beneficial owner (0ECD, 2011). The Conduit Companies Report supported this statement by explaining that, even though the conduit company was the 'formal owner' of an asset with 'narrow powers' in relation to the income, the company could not be the beneficial owner (OECD, 2003). The Prévost and Indofood cases relied on the views of the OECD to reach the same decision with regard to agents, nominees and conduit companies. The judge in the Prévost case stated that, if property is in the name of a nominee and the nominee is acting in accordance with another person's instructions, one has to consider on whose behalf the nominee is acting. The Indofood case excluded administrators of income as beneficial owners (Kemmeren, 2012).

Based on the OECD's reasoning for excluding intermediate recipients, it is necessary, firstly, to determine whether the trustees have the full right to use and enjoy the dividend that is received and, secondly, to ascertain whether the trustees have limited powers over the dividend because of their fiduciary duty or other duty which obligates the trustee to pass the payment received on to the beneficiary $(0 E C D, 2011)$. A further practical test looked at the degree of legal responsibility in managing the conduit. The greater the degree of management responsibility, the more likely it is that the conduit will be the beneficial owner of the income (Krishna \& Gervais, 2009).

In section 5 , the nature of the office of trustee is described. Section 1 of the Act clearly stipulates that the trustee is acting in a fiduciary capacity. The Trust Property Control Act further gives instruction that this fiduciary responsibility should be carried out 'as is reasonably expected of someone who manages the affairs of another'. This clearly points towards limited powers over the dividend income. Furthermore, the extent of the trustees' powers is determined by the trust deed (Olivier, 1990), which is legally enforceable by court order in terms of section 19 of the Trust Property Control Act. The trustees are thus acting in accordance with instructions in the trust deed and may not deviate from it without legal consequences as set out in the Trust Property Control Act (section 19).

In terms of parameters one and two, it can thus be concluded that the trustees do not have the full right to use and enjoy the dividend. As a result of this fiduciary responsibility, it renders the trust as similar to an agent or nominee or conduit company. The trust beneficiaries, therefore, will again be the beneficial owners of the dividend income as retained by the trust.

However, in the case where a trust beneficiary has contingent rights also referred to as a contingent beneficiary, the position of the trust as possible agent, nominee or conduit might be different. 
A contingent beneficiary arises when the trust deed provides that the beneficiary's ability to claim payment of income is conditional or contingent upon the occurrence of an uncertain future event (Du Toit, 2002). Before the contingency has taken place or the condition has been fulfilled, the beneficiary has only a contingent right to the income. This equates to a mere expectation or 'spes' which will not be an asset in the beneficiary's estate (Du Toit, 2002). In terms of the practical test for identifying a conduit, there could be a greater degree of management responsibility, making the trust the beneficial owner of the dividend income.

\section{TIMING OF THE DISTRIBUTION OF DIVIDENDS RECEIVED BY THE DISCRETIONARY TRUST}

In addition to the steps identified and discussed above, the timing of the distribution of the dividend might significantly affect the determination of the beneficial owner of dividend income in the case of a dividend received by a discretionary trust. Section $64 \mathrm{~K}(\mathrm{l})$ of the Act places the responsibility or liability for paying the dividends tax on the beneficial owner on or before a certain date after the dividend was declared by a company.

Section $64 \mathrm{~K}(1)(\mathrm{a})$ of the Act stipulates that where the beneficial owner is liable for dividends tax in respect of a dividend, the beneficial owner is responsible to pay the amount due to the Commissioner by the last day of the month following the month during which that dividend is paid by the company that declared that the dividend, unless such tax has been paid by another person. In the context of the discretionary trust, should this date of payment fall between the date that the dividend has been declared to the trust, but before the trust beneficiaries have a vested right to the dividend income, the trust will be responsible for payment of the dividends tax. On the other hand, should the trust beneficiary have acquired a vested right to dividend income before the dividends tax becomes payable, the trust beneficiaries will be responsible for the payment of the dividends tax.

Taking the effect of section $64 \mathrm{~K}(\mathrm{l})$ into account, it is argued that, depending on the timing of the distribution of the dividend by the trustees, they or the beneficiaries by default become the beneficial owners.

\section{CONCLUSION}

This paper aimed to set parameters for determining who the beneficial owner of dividend income within the context of a discretionary trust is. Particular attention was given to where the dividend is paid in respect of shares held in a resident company, and to the extent that the dividend does not consist of a distribution of an asset in specie.

Firstly, the proposed meaning of beneficial owner was analysed according to local and international literature and case law available. From this analysis, a number of factors were identified to consider in determining the beneficial owner for dividends tax purposes. Factors identified included legal versus beneficial ownership of the underlying share, the rights and attributes of ownership in respect of the dividend income, whether the taxpayer acted as a conduit in respect of the dividend income, and finally, the timing of the distribution of the dividend income by the discretionary trust. 
As summarised in FIGURE 5, the trustees remain the legal owner of the underlying shares giving rise to the dividend income, whilst the trust beneficiaries are the beneficial owner of the underlying shares.

In the case of the dividend income having been distributed by the trustees following the exercise of their discretion in terms of the trust deed, FIGURE 5 illustrates that the trust beneficiary remains the beneficial owner of dividend income. This is by virtue of the ownership rights or attributes that they possess in relation to the dividend income. This conclusion remains unaffected by the timing of the distribution.

In the event of the trust having contingent beneficiaries and no discretion being exercised by the trustees, the trust beneficiaries might not have full rights to, or enjoyment of, the income. In addition, the greater weight of ownership might lie with the trustees and, consequently, with the trust. In the case of contingent beneficiaries, it is suggested that the trust, with the trustees acting in their official capacity on behalf of the trust, could be seen as the beneficial owner of the dividend income.

Finally, taking the effect of section $64 \mathrm{~K}(1)$ into account, it is argued that, depending on the timing of the distribution of the dividend by the trustees, they or the beneficiaries by default become the beneficial owners.

\section{LIST OF REFERENCES}

Baker, P. (2007). Beneficial Ownership: After Indofood. Grays Inn Tax Chamber Review, 6(1), Available at: http://www.taxbar.com/documents/Beneficial_Ownership_PB.pdf. (Accessed 25 July 2012).

Braun v Blann\& Botha (1984(2) SA 850(A).

De Koker, A.P. \& Williams, R.C. 2011 . Silke on South African Income Tax. Durban: LexisNexis.

Du Toit, C. (2010). The evolution of the term "Beneficial Ownership" in relation to International Taxation over the past 45 years. Bulletin for International Taxation. IBFD.

Du Toit, F. (2002). South African trust law: principles and practice. Durban: LexisNexis.

Ernst \& Young (2011). OECD proposes clarifications to the meaning of beneficial owner in the OECD Model Tax Convention. Available at: http://www.ey.com/Publication/vwLUAssets/TPC8_Beneficial_0wner_8_Sept_2011/\$FILE/TPC8_Ben eficialOwner_8Sept2011.pdf. (Accessed 29 0ctober 2012).

Federal Administrative Tribunal Judgement A-6537/2010 of 7 March 2012.

Geach, W.D. (2007). Trusts: law and practice. Cape Town. Juta.

HogeRaad, 6 April, 1994, No 28 638, BNB 1997/21.

Honiball, M. \& Olivier, L. (2011). International Tax: A South African Perspective. 5th Edition. Cape Town: Siberink.

Honoré, T. \& Cameron, દ. (1992). Honoré's South African law of trusts. 4th Edition. Cape Town: Juta. Interfis, (2009). Treaty shopping. Available at: http://www.interfis.com/articles/treaty-shopping. (Accessed 19 December 2012). 
International Bureau for Fiscal Documentation (IBFD). (2011). Clarification of the meaning of "Beneficial Owner" in the OECD Model Tax Convention. Available at: http://www.oecd.org/tax/taxtreaties/48413407.pdf. Amsterdam: IBFD. (Accessed 6August 2012).

Kemmeren, C.C.M. (2012).Concept of Beneficial Owner in the Dutch Tax System and DTC's. Tilburg: Tilburg University. Available at: http://www.ideff.pt/xms/files/Iniciativas/Handout__EK.pdf. (Accessed 25 July 2012).

Krishna, V. \& Gervais, B.L. (2009). Treaty Shopping and the Concept of Beneficial Ownership in Double Tax Treaties. Canadian Current Tax, 19(11):129-149.

Kruger, D. (2012). Who is a Beneficial Owner?, Business Tax and Company Law Quarterly, 3:1, Siber Ink: Cape Town

Land and Agricultural Bank of SA v Parker and others (2005 (2) SA 77 (SCA).

Louw, H. (2012). Dividend tax and trusts. Money Web Tax. Available at:

http://www.moneywebtax.co.za/moneywebtax/view/moneywebtax/en/pagelMoneywebtax/page266 ?oid=67142\&sn=Detail\&pid=266. (Accessed 21 June 2012).

National Treasury. South Africa. (2012). Explanatory memorandum on the Taxation Laws Amendment Bill, 2011. Pretoria: Government Printer.

Olivier, P.A. (1990). Trust law and practice. Pretoria West: Gutenberg Book Printers.

Oliver, J.D.B., Libin, J., Van Weeghel, S. \& Du Toit C. (2000). "Beneficial Ownership”. Bulletin. IBFD. July 2000.

Organisation for Economic Co-operation and Development (OECD). (2011). Clarification of the meaning of 'beneficial owner' in the OECD Model Tax Convention. Paris: OECD.

Organisation for Economic o-operation and Development (OECD). 2010. Model Tax Convention on Income and On Capital. Paris: OECD.

Prévost Car Inc. v The Queen 2008 TCJ 231.

PricewaterhouseCoopers (PWC). (2012). Beneficial owner - Canada shows the way, PWC Synopsis. Available: http://www.pwc.co.za/en/assets/pdf/synopsis-april-2012.pdf. (Accessed 30 May 2012).

PricewaterhouseCoopers (PWC). (2012). Swiss administrative court decision on beneficial ownership in equity finance transactions. Newsalert: Banking and Capital Market, March 2012. Available: (http://www.pwc.com/en_SG/sg/taxbulletin/assets/taxbulletin201204.pdf. (Accessed 19 December 2012).

Peters, M. (2012). Beneficial Owner - CRA's assessment of Velcro doesn't stick. FMC Law. Available at: http://www.dentons.com/en/insights/articles/2012/february/27/beneficial-owner----cra-sassessment-of-velcro-doesn-t-stick---february-2012.(Accessed 13 July 2012).

Ryynänen, 0. 2009. The Concept of a Beneficial Owner in the Application of Finnish Tax Treaties. Scandinavian studies in law, 44, pp. $345-366$.

South African Revenue Service (SARS). (2012). Interpretation Note: 43 (Issue 4). Pretoria: Government Printer. Available at: http://jutalaw.co.za/media/filestore/2012/11/3_IN_43.pdf. (Accessed 3 July 2014).

South African Revenue Service (SARS). (2012). Binding Private Ruling: BPR 125. Pretoria: Government Printer. Available at: http://jutalaw.co.za/media/filestore/2012/11/8_BPR_125.pdf. (Accessed 3 July 2014). 
South Africa. (1962). South Africa Income Tax Act, 58 of 1962. Pretoria: Government Printer.

South Africa. (2011). Tax Administration Act, 28 of 2011. Pretoria: Government Printer.

South African Institute for Chartered Accountants (SAICA). (2009). Beneficial owner of a dividend for double tax agreements. Available at:

http://www.saica.co.za/integritax/2009/1798_Beneficial_owner_of_a_dividend_for_double_tax_a greements.htm. (Accessed 30 July 2013).

Stiglingh, M., Koekemoer, A., van Schalkwyk, L., Wilcocks, J.S., \& de Swardt, R.D. (2013). Silke: South African Income Tax 2012. Durban: LexisNexis.

Trust Property Control Act, 57 of 1988.

Velcro Canada Inc v The Queen 2012 TCC 57.

Vitko, A. 2011. Fiscal meaning of the Concept "Beneficial Owner". Master's dissertation. Lund: Lund University. Available

at:http://lup.lub.lu.se/luur/download?func=downloadFile\&recordOId=1983706\&file0Id=1983710. (Accessed 12 July 2012). 
Engelbrecht 